\title{
Mass Spectrometry of 1,2,5-Oxadiazole $N$-Oxide Derivatives. Use of Deuterated Analogues in Fragmentation Pattern Studies
}

\author{
Hugo Cerecetto $^{a}$, Mercedes González $^{*, a}$, Gustavo Seoane ${ }^{a}$, Carola Stanko ${ }^{a}$, Oscar E. Piro ${ }^{b}$ \\ and Eduardo E. Castellano \\ ${ }^{a}$ Departamento de Química Orgánica, Facultad de Química - Facultad de Ciencias, Universidad de la República. \\ CC 1157, Gral. Flores 2124, 11800 Montevideo, Uruguay \\ ${ }^{b}$ Departamento de Física, Facultad de Ciencias Exactas, Universidad Nacional de La Plata, CC 67, 1900 \\ La Plata, Argentina \\ ${ }^{c}$ Instituto de Física de São Carlos, Universidade de São Paulo, CP 369, 13560 São Carlos - SP, Brazil
}

\begin{abstract}
Reportamos neste trabalho o estudo sistemático de fragmentação dos derivados de $N$-óxidos de 1,2,5-oxadiazóis por espectroscopia de massa, usando análogos marcados com deutério para identificar algumas fragmentações críticas. Foi confirmada a perda neutra de $\mathrm{CH}_{2} \mathrm{O}$ a partir do $\mathrm{N}_{2}$-óxido de 3hidroximetil-4-fenil-1,2,5-oxidiazol, usando o análogo mono-deuterado. A perda de $\mathrm{OH}$, a partir do oxigênio do $N$-óxido, por um rearranjo $\beta$-H e $\delta$ - $\mathrm{H}$, foi claramente verificada a partir do $\mathrm{N}_{2}$-óxido de 3-(4-metilpiperazina-1-metil)-4-fenil-1,2,5-oxidiazol, usando-se o analogo tetra-deuterado adequado. $\mathrm{O}$ isômero $N$-óxido e análogos desoxigenados foram também usados para confirmar a participação do fragmento óxido no processo de defragmentação.
\end{abstract}

This paper reported on the study of fragmentation pattern in mass spectrometry of 1,2,5-oxadiazole $\mathrm{N}$-oxide derivatives involving deuterium-labeled analogues to identify some critical fragmentations. A neutral $\mathrm{CH}_{2} \mathrm{O}$ loss from 3-hydroxymethyl- $\mathrm{N}_{2}$-oxide-4-phenyl-1,2,5-oxadiazole was confirmed with the corresponding mono-deuterated analogue. An $\mathrm{OH}$ loss, involving the oxygen of $\mathrm{N}$-oxide, via $\beta$-H and $\delta$-H rearrangement, was clearly revealed from 3-(4-methylpiperazine-1-ylmethyl)- $N_{2}$ oxide-4-phenyl-1,2,5-oxadiazole using the adequate tetra-deuterated analogue. $N$-oxide isomer and deoxygenated analogues were also used to confirm the participation of the oxide moiety in the fragmentation process.

Keywords: 1,2,5-oxadiazole $N$-oxide, D-labeled furoxan, mass fragmentation, EI/MS

\section{Introduction}

As part of an ongoing research program on the chemistry and biological characterization of $\mathrm{N}$-oxide containing molecules, a number of 1,2,5-oxadiazole $N$-oxide, benzo[1,2-c]1,2,5-oxadiazole $N$-oxide, quinoxaline $N, N$ 'dioxide, and 1,2,4-triazine $N$-oxide derivatives were synthesized and evaluated against different biological targets. ${ }^{1}$ In the course of our synthetic chemical approach we developed 1,2,5-oxadiazole $N$-oxide derivatives as potential herbicides, ${ }^{2}$ bioreductive compounds, ${ }^{3-6}$ and antitrypanosomal drugs, ${ }^{7,8}$ using previously described synthetic methods. ${ }^{9}$ During the structural elucidation of

*e-mails: megonzal@fq.edu.uy these derivatives, we were interested in knowing about the presence and the exact location of the $\mathrm{N}$-oxide functionality. Simple and readily available spectroscopic techniques (e.g. IR and ${ }^{1} \mathrm{H}$ NMR) are not able to unambiguously characterize the presence of an $\mathrm{N}$-oxide group. For example, the characteristic IR absorptions of $=\mathrm{N}^{+}-\mathrm{O}^{-}\left(1300-1200 \mathrm{~cm}^{-1}\right.$ and $\left.970-950 \mathrm{~cm}^{-1}\right)$ are not considered a conclusive proof because these bands can overlap with the fingerprint bands. ${ }^{10}$ Similarly, ${ }^{1} \mathrm{H}$ NMR spectroscopy can not afford important information about the $=\mathrm{N}^{+}-\mathrm{O}^{-}$system, because these products are heterocycles devoid of protons. However, more recently 2D-HETCOR experiments (sequences of $\mathrm{HMQC}$ for one-bond correlation and sequences of HMBC for long distance/carbon correlation) provide us very important data about the presence and position of the $=\mathrm{N}^{+}-\mathrm{O}^{-}$moiety. 
In this context, the initial aim of the present study was to characterize the fragmentation pattern in mass spectrometry of the 1,2,5-oxadiazole $\mathrm{N}$-oxide derivatives as an alternative structural determination technique. On the other hand, this work describes the elucidation of the fragmentation patterns of these compounds through the use of deuterated derivatives, ${ }^{11} \mathrm{~N}$-oxide isomer and deoxygenated (without $N$-oxide) analogues. ${ }^{12}$

\section{Results and Discussion}

The spectra for selected derivatives 1-13 (Figure 1) revealed different fragmentation patterns, resulting from different side chains of the 1,2,5-oxadiazole heterocycle at $\mathrm{C}-3$. The most relevant mass spectral data for derivatives 1-13 are presented in Table 1 and Figure 2 rationalizes important fragmentation pathways.

The molecular ion was detected in all cases. However, the abundances were very low for derivatives 4-6, which contain a residue proven to undergo retro-Diels-Alderfragmentation (morpholine, thiomorpholine, and methylpiperazine). ${ }^{13}$ The same was observed for derivative 12, that bears an aliphatic side chain on the semicarbazone moiety. The $[\mathrm{M}-16 \mathrm{u}]^{+\bullet}$ ion, corresponding to an oxygen loss, was observed in all cases as a relatively small peak. However, the peak corresponding to $m / z[\mathrm{M}-17 \mathrm{u}]^{+}$, became increasingly important for derivatives 4-7 and $\mathbf{1 1}$ as result of an $\mathrm{OH}^{*}$ loss. This kind of fragmentation has been previously described for similar moieties, e.g., a $\mathrm{NO}_{2}$ group losses $\mathrm{OH}^{*}$ in $o$-nitrotoluenes and $o$-nitroanilines, ${ }^{13}$ or for other adequately substituted $N$-oxide heterocycles. ${ }^{14,15} \mathrm{In}$ these compounds, two different rearrangement processes could explain this radical loss, $\beta$-H and/or $\delta$-H rearrangement (Figure 3 ). The high abundance of this fragment ion for derivatives 4-7 (non-aromatic cyclic amine derivatives) compared to fragment ion abundance's for derivatives 8-10 (phenylamino derivatives) made us to think that a $\delta$ - $\mathrm{H}$ rearrangement was the main process in this kind of structures. With a conventional EI/MS equipment it is not possible to study this fact and others, e.g., to determine whether the $[\mathrm{M}-30 \mathrm{u}]^{+}$fragment ion in derivative $\mathbf{1}$ corresponds to a NO loss (as for the other derivatives) or a $\mathrm{CH}_{2} \mathrm{O}$ loss from the hydroxymethyl substituent in 3-position of the 1,2,5oxadiazole heterocycle is due to an initial $\gamma-\mathrm{H}$ transference, which produces the stable neutral-product formaldehyde (Figure 4).

In order to explain these critical fragmentations in mass spectrometry, using a EI/MS equipment, we centered our

Table 1. Abundance of the most characteristic fragment ions in the corresponding 1,2,5-oxadiazole $\mathrm{N}$-oxide derivatives EI mass spectrum

\begin{tabular}{lrrrrrr}
\hline $\begin{array}{c}\text { Compound } \\
\text { No }\end{array}$ & \multicolumn{7}{c}{ Abundance $(\%){ }^{\mathrm{a}, \mathrm{b}}$} \\
\hline $\mathbf{1}$ & 15.7 & 0.5 & 0.2 & 20.7 & 58.0 & 100.0 \\
$\mathbf{2}$ & 27.6 & 0.5 & 0.2 & 25.5 & 62.5 & 100.0 \\
$\mathbf{3}$ & 12.0 & 0.3 & 0.3 & 10.6 & 35.3 & 1.7 \\
$\mathbf{4}$ & 0.8 & 0.9 & 4.1 & 0.2 & 0.3 & 0.7 \\
$\mathbf{5}$ & 0.8 & 1.9 & 11.8 & 1.3 & 0.2 & 0.3 \\
$\mathbf{6}$ & 0.3 & 8.5 & 50.4 & 0.2 & 1.0 & 0.8 \\
$\mathbf{7}$ & 10.0 & 7.1 & 33.8 & 0.6 & 0.2 & 0.3 \\
$\mathbf{8}$ & 10.6 & 1.1 & 0.1 & $-{ }^{+}-16$ & 1.1 & 2.6 \\
$\mathbf{9}$ & 12.1 & 2.1 & - & - & 1.1 & 2.5 \\
$\mathbf{1 0}$ & 21.2 & 3.9 & 1.7 & - & 1.6 & 1.6 \\
$\mathbf{1 1}$ & 10.6 & 3.5 & 11.3 & 57.6 & 55.5 & 6.8 \\
$\mathbf{1 2}$ & 0.2 & 0.2 & 0.8 & 31.8 & 7.3 & 0.3 \\
$\mathbf{1 3}$ & 2.3 & - & - & 7.5 & 13.3 & - \\
\hline
\end{tabular}

${ }^{a}$ Analytical conditions for EI/MS: direct injection, ion source temperature $250{ }^{\circ} \mathrm{C}$, energy $70 \mathrm{eV}$. ${ }^{\mathrm{b}}$ The results are the averages for three independent experiments. " The "-" denotes that the fragment ion was not observed.

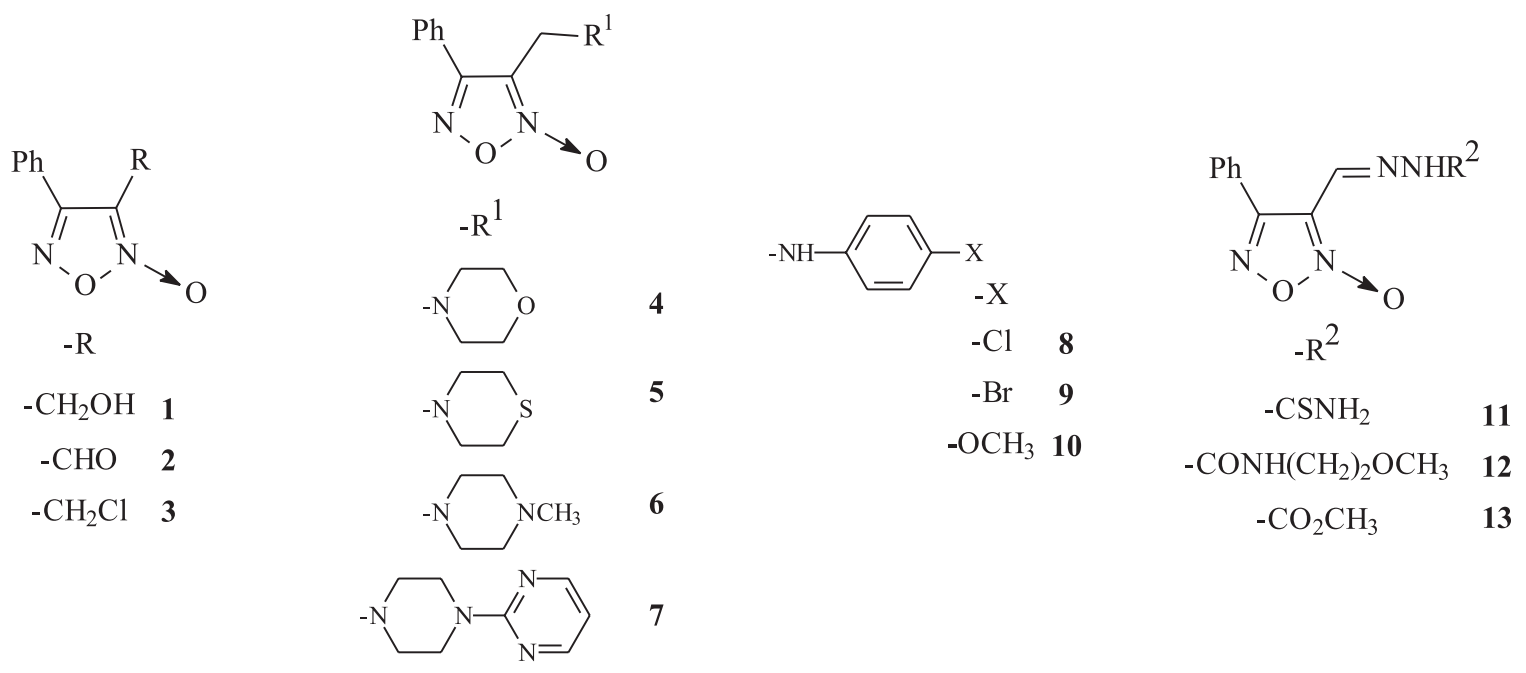

Figure 1. Series of 1,2,5-oxadiazole $N$-oxide developed in order to study their biological activity. 


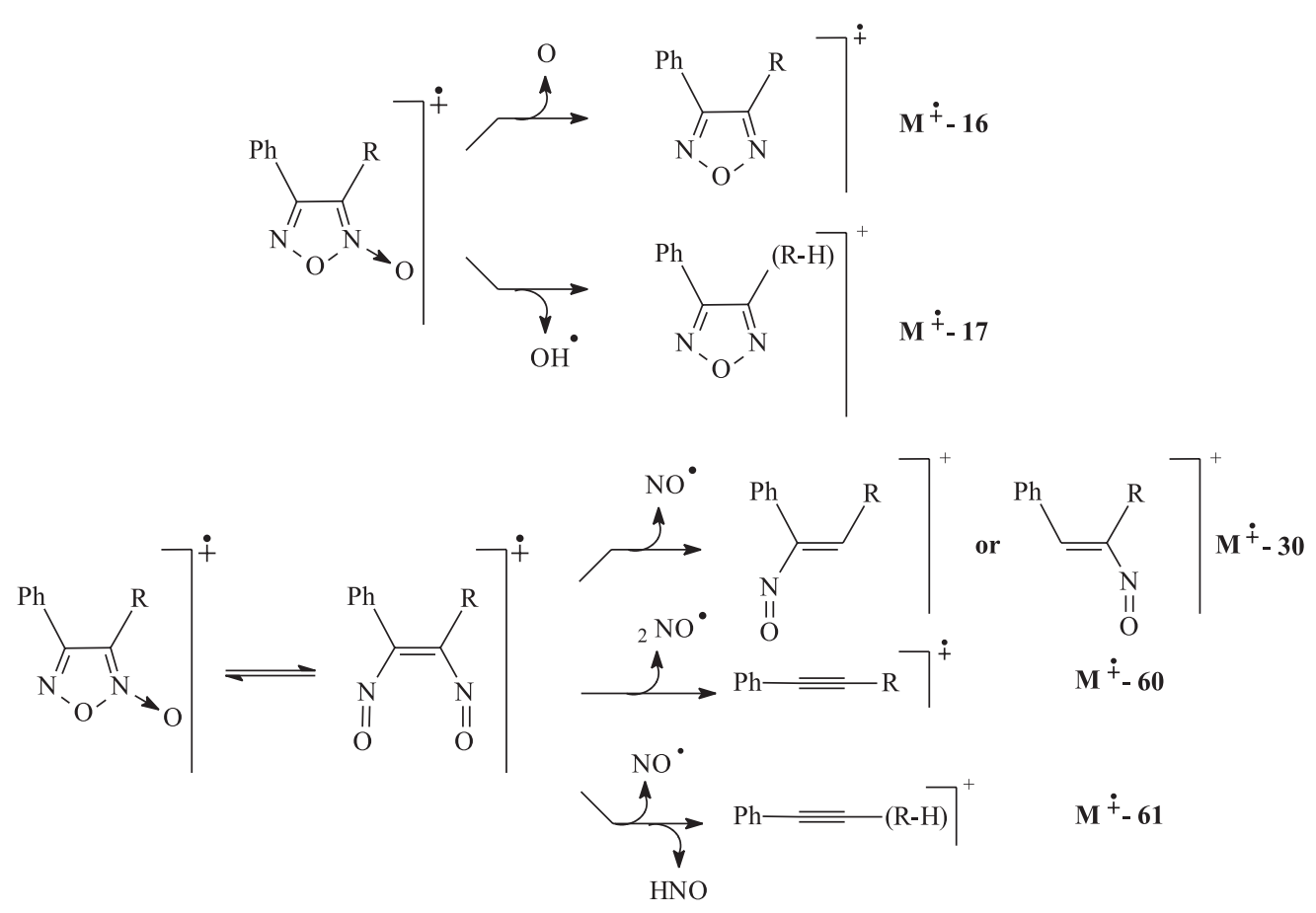

Figure 2. Most characteristic fragment ions in the 1,2,5-oxadiazole $N$-oxide derivatives EI mass spectrum.<smiles>c1ccc(-c2no[n+]3c2CN2C(CCC4CCCCC42)C3)cc1</smiles><smiles>[CH]C=CC=CC</smiles>

$-\mathrm{X}$

$$
-\mathrm{O}
$$$$
-\mathrm{S}
$$$$
\text { -N-(pyrimidine-2-yl) } 7
$$<smiles>[X]C1CCN(Cc2c(-c3ccccc3)no[n+]2O)CC1</smiles>

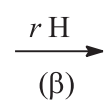<smiles>O[n+]1onc(-c2ccccc2)c1CN1CCCCC1</smiles><smiles></smiles>

or<smiles>[X][n+]1onc(-c2ccccc2)c1CN1CCCCC1</smiles>

Figure 3. Postulated mechanism for the $\mathrm{OH}^{\bullet}$ loss in compounds 4, 5, 6 and $\mathbf{7}$ (Note: we are gratefully thank to one of the referee for suggesting the structure of the final product of the $\delta$-H rearrangement).

efforts on the synthesis of deuterium analogues of some selected furoxan derivatives. ${ }^{16,17}$ Initially, we tried to prepare di-deuterium analogue, at the benzylic position, of derivative $\mathbf{6}$. The synthesis of the di-deuterium chloride 3 was attempted by trying to exchange the "acidic" benzylic-protons using a biphasic system NaOD- $\mathrm{D}_{2} \mathrm{O} /$ $\mathrm{CDCl}_{3}$ at different temperatures (room temperature to reflux for $24 \mathrm{~h}$ ) (as shown in Scheme 1). Unfortunately, ${ }^{1} \mathrm{H}-\mathrm{NMR}$ monitoring of the reaction mixture showed no significant exchange under these conditions. When $\mathrm{CD}_{3} \mathrm{O}^{-} \mathrm{Na}^{+} /$ $\mathrm{CD}_{3} \mathrm{OD}$ was used, exchange took place, but the ether $\mathbf{1 4}$ was obtained as the result of the substitution by the powerful nucleophile deuterated methoxide (Scheme 1). These synthetic problems led us to undertake the preparation of the mono-deuterium analogue of derivative $\mathbf{6}$, at the benzylic position, with $\mathbf{3}-d_{1}$ as starting material (Scheme 1). Using the aldehyde $\mathbf{2}$, the mono-deuterium alcohol 1- $d_{1}$ was produced with more than $95 \%$ of 

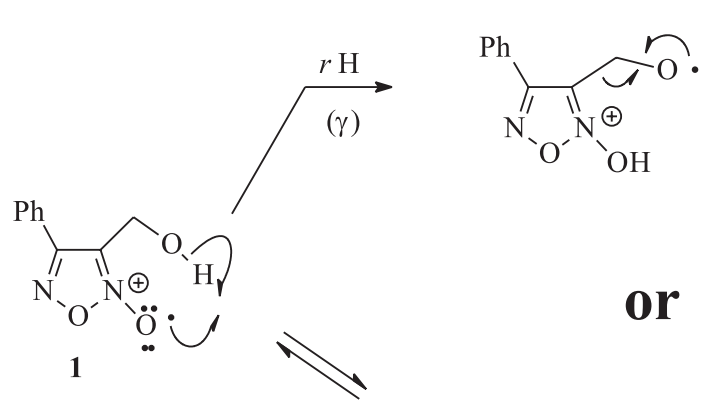<smiles>CCCO</smiles>

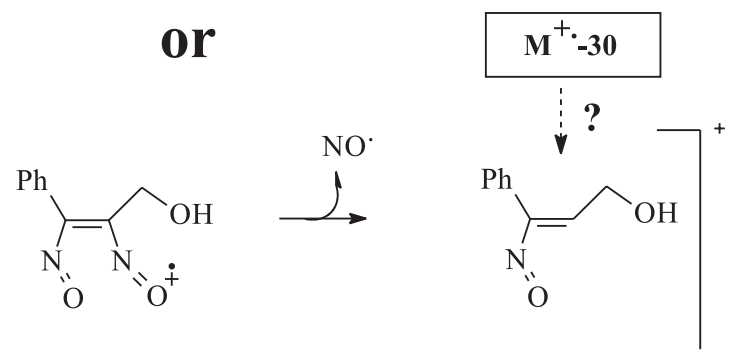

Figure 4. Postulated mechanism for the $\mathrm{NO}^{*}$ and $\mathrm{CH}_{2} \mathrm{O}$ loss in compounds $\mathbf{1}$.<smiles>ON1ON=C(c2ccccc2)C1CCl</smiles>

3<smiles>O=Cc1c(-c2ccccc2)no[n+]1[O-]</smiles>

2
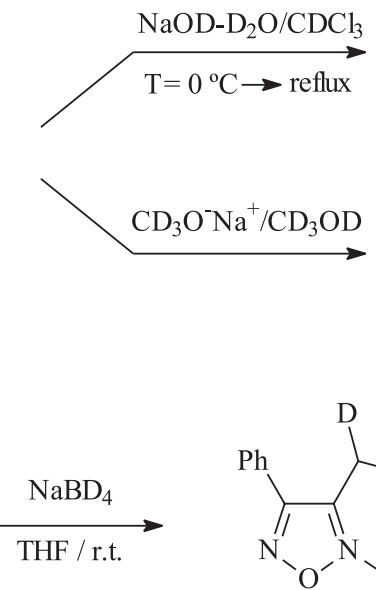

THF / r.t.<smiles></smiles>

$1-d 1$<smiles>[2H]C([2H])(Cl)c1c(-c2ccccc2)no[n+]1[O-]</smiles>

NO REACTION<smiles>[2H]C(OC)c1c(-c2ccccc2)no[n+]1[O-]</smiles>

14

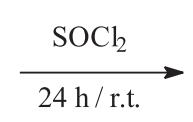<smiles></smiles>

3- $d 1$

Scheme 1.

deuterium incorporation verified by ${ }^{1} \mathrm{H}-\mathrm{NMR}$ analysis, employing the deuterated-metal reductor-NaBD (Scheme $^{-}$ 1 ). The $\mathrm{N}$-oxide moiety was maintained in position $N_{2}$ during the reaction of derivative $\mathbf{2}$ with sodium borodeuteride. This fact was observed through the corresponding 2D-NMR experiments, which showed a quaternary carbon (HMQC experiment) at $115.36 \mathrm{ppm}$ correlating with a proton at $4.73 \mathrm{ppm}$ (HMBC experiment) and another quaternary carbon (HMQC experiment) at $157.31 \mathrm{ppm}$ correlating with protons at $4.73 \mathrm{ppm}$ and 7.84 ppm (HMBC experiment). These HETCOR experiments allowed us to assign unambiguously the heterocyclic carbon atoms $\left(\mathrm{d}_{\mathrm{C}-3}=115.36 \mathrm{ppm}, \mathrm{d}_{\mathrm{C}-4}=157.31 \mathrm{ppm}\right)$ (Figure $5)$. The product $1-d_{1}$ was then transformed in a good yield into the corresponding chloride $\mathbf{3}-d_{1}$ using thionyl chloride (Scheme 1).

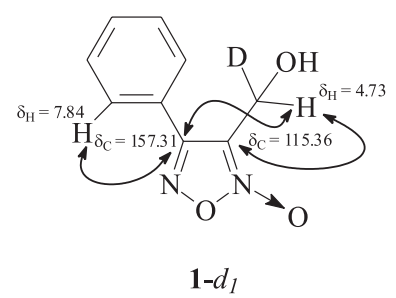

Figure 5. HMBC correlation for derivative 1- $d_{1}$.

Finally, the amine derivative 6- $d_{1}$ was obtained by the reaction between chloride $3-d_{1}$ and $N$-methylpiperazine (Scheme 2). The molecular structure of derivative 6- $d_{1}$ has been determined by X-ray diffraction methods (Figure 6). ${ }^{18,19}$ In addition, we prepared $\mathbf{6}-d_{4}$, the tetra-deuterium analogue in the 2,6-position of piperazine ring, through reaction between the chloride 3 and the heterocyclic amine 


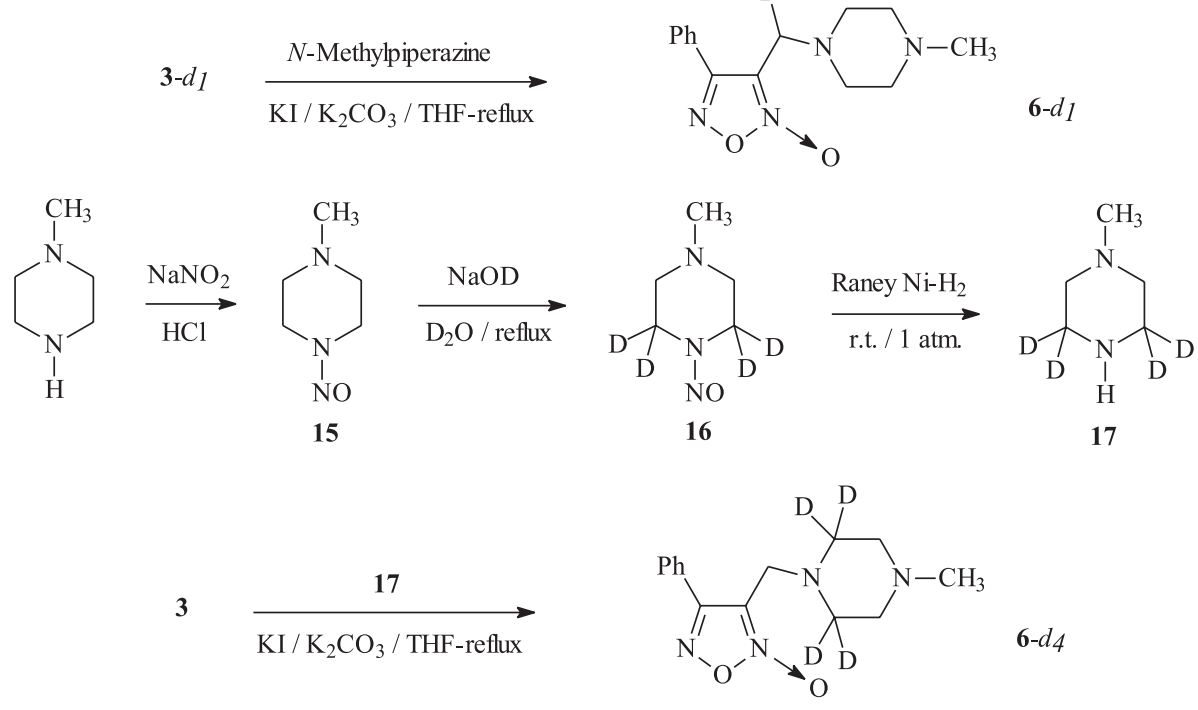

Scheme 2.

17 (Scheme 2). This amine was deuterated via the nitrosamine 15, prepared following the Ravindran et al. procedure, ${ }^{20}$ which was converted into the tetra-deuterium analogue $\mathbf{1 6}$ following the Keefer-Fodor methodology. ${ }^{21}$ To transform nitrosamine $\mathbf{1 6}$ into amine $\mathbf{1 7}$ we tried a procedure by Kano et al. (reduction with $\mathrm{NaBH}_{4}: \mathrm{TiCl}_{4}(2: 1)$ in diglyme) with bad results. ${ }^{22}$ The reduction process did not occur and probably, a complex between the methylpiperazine nitrosamine and $\mathrm{TiCl}_{4}$ was obtained. The use of $\mathrm{H}_{2}$ in Raney-Nickel at room temperature and atmospheric pressure led to compound $\mathbf{1 7}$ in an adequate yield. ${ }^{23}$ The deuterium incorporation in compound $\mathbf{1 6}$ was more than $95 \%$ (by ${ }^{1} \mathrm{H}-\mathrm{NMR}$ analysis).

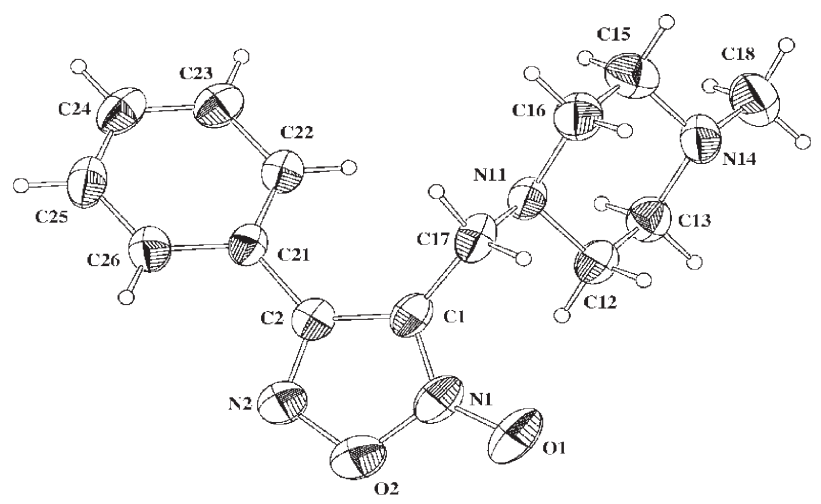

Figure 6. Molecular plot of derivative 6- $d_{l}$. The ORTEP drawing of the molecule shows the labeling of the non-H(D) atoms and their displacement ellipsoids at $30 \%$ probability level.

To know how the $N$-oxide group position affect on the furoxans' mass spectrometry behavior, we prepared the $N$ oxide-positional isomer 3-i. This compound was obtained via the alcohol 1-i, which was prepared following the Gasco et al. methodology (Scheme 3). ${ }^{10}$ To study the fragmentation patron of the molecule " $N$-oxide-free", we prepared the deoxygenated analogues 1-deoxy and 7-deoxy using $\mathrm{Zn}$ in $\mathrm{NH}_{4} \mathrm{Cl}$ solution as the reduction reagent (Scheme 3). ${ }^{6,24}$ These products were clearly confirmed through HETCOR experiments (HMQC and HMBC).

Mass spectrometry was carried out on all the analogues developed. The most characteristic peaks in the mass spectrum (EI/MS) for derivatives 1- $d_{1}, \mathbf{1 - d e o x y , ~ 3 - ~} d_{1}, \mathbf{3 - i}$, 6- $d_{1}, \mathbf{6}-d_{4}$ and 7-deoxy, together with those for parent compounds $1,3,6$ and 7 , are presented in Table 2. The results clearly indicate that the fragmentation process of compound 1- $d_{1}$ does not occur exclusively through a NO* loss, the $[\mathrm{M}-31 \mathrm{u}]^{+*}$ ion (not present in the parent compound 1) probably arise from a CDHO loss. On the other hand, comparing the relative abundance of the $\mathrm{M}^{+*}$ and $[\mathrm{M}-30 \mathrm{u}]^{+*}$ ions in compounds 1-deoxy and 7-deoxy, 9.9\% and 1.6\% respectively, we could notice that the $[\mathrm{M}-30 \mathrm{u}]^{+\cdot}$ ion was more abundant in the first one, this fact is in accordance with the neutral $\mathrm{CH}_{2} \mathrm{O}$ loss fragmentation process in derivative 1.

The mass spectrum of positional isomer 3- $i$ did not show the $[\mathrm{M}-17 \mathrm{u}]^{+\bullet}$ and $[\mathrm{M}-31 \mathrm{u}]^{+*}$ ions, this fact could be indicative that the parent compound 3 losses $\mathrm{OH}$ and $\mathrm{HNO}$ as a $\beta-\mathrm{H}$ participation. Deuterium labeling of compound $\mathbf{6}$ indicated that the $[\mathrm{M}-17 \mathrm{u}]^{+*}$ ion of this derivative was the result of $\beta-\mathrm{H}$ and $\delta$-H rearrangements (see Table 2). While derivative 6 showed an $[\mathrm{M}-17 \mathrm{u}]^{+*}$ ion abundance of $50.4 \%$, derivatives mono- and tetra-deuterated (6- $d_{1}$ and $\left.\mathbf{6}-d_{4}\right)$, that could present the $\beta-\mathrm{H}$ and the $\delta$-H rearrangement phenomena, showed the abundances of the corresponding 
<smiles></smiles>

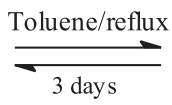

1

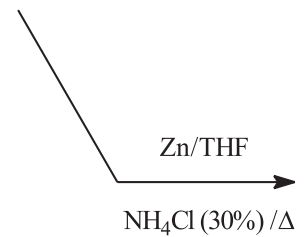<smiles>O=[N+]([O-])Cc1ccccc1</smiles>

1-i<smiles>OCc1nonc1-c1ccccc1</smiles>

1-deoxy<smiles>O[n+]1onc(-c2ccccc2)c1CN1CCN(c2ncccn2)CC1</smiles>

7<smiles>CCOCC</smiles><smiles>[O-][n+]1onc(CCl)c1-c1ccccc1</smiles>

$3-i$

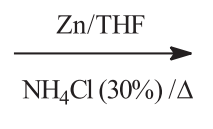

Scheme 3.<smiles>CC(C)(C)OCc1nonc1CN1CCN(c2ncccn2)CC1</smiles>

Table 2. Abundance of the critical fragment ions in the corresponding 1,2,5-oxadiazole $N$-oxide analogues EI mass spectrum

\begin{tabular}{|c|c|c|c|c|c|c|c|c|c|}
\hline \multirow[b]{2}{*}{ Compound No } & \multirow[b]{2}{*}{$\mathrm{M}^{+}$} & \multirow[b]{2}{*}{$\mathrm{M}^{+\bullet}$} & \multicolumn{6}{|c|}{ Abundance $(\%)^{\mathrm{a}, \mathrm{b}}$} & \multirow[b]{2}{*}{$\mathrm{M}^{+\bullet}-62$} \\
\hline & & & $\mathrm{M}^{+\bullet}-16$ & $\mathrm{M}^{+\bullet}-17$ & $\mathrm{M}^{+\bullet}-18$ & $\mathrm{M}^{+\bullet}-30$ & $\mathrm{M}^{+\bullet}-31$ & $\mathrm{M}^{+\bullet}-61$ & \\
\hline 1 & 192 & 15.7 & 0.5 & 0.2 & 0.6 & 20.7 & $-c$ & 100.0 & 0.8 \\
\hline $1-d$ & 193 & 25.6 & 1.7 & 0.6 & 1.1 & 27.8 & 3.0 & 100.0 & 20.4 \\
\hline 1-deoxy & 176 & 100.0 & 0.2 & 1.2 & 0.3 & 9.9 & 3.5 & 8.2 & 6.0 \\
\hline 3 & 210 & 12.0 & 0.3 & 0.3 & - & 10.6 & 0.1 & 1.7 & 0.1 \\
\hline $3-d_{1}$ & 211 & 12.2 & 0.2 & 0.3 & 0.1 & 11.4 & 1.2 & 4.7 & 0.3 \\
\hline $3-i^{T}$ & 210 & 8.6 & 0.1 & - & - & 6.9 & - & 1.6 & - \\
\hline 6 & 274 & 0.3 & 8.5 & 50.4 & 0.4 & 0.2 & 0.2 & 0.8 & 0.3 \\
\hline $6-d_{1}$ & 275 & 1.2 & 7.7 & 45.6 & 23.0 & 0.3 & - & 0.7 & 0.5 \\
\hline 6- $d_{4}$ & 278 & 0.3 & 8.7 & 46.2 & 17.0 & - & - & 0.4 & 0.1 \\
\hline $6-d_{4}^{4}$ & 278 & 4.6 & 17.1 & 100.0 & 35.5 & 0.3 & - & 2.6 & 0.9 \\
\hline 7 & 338 & 10.0 & 7.1 & 33.8 & 0.2 & 0.6 & 0.2 & 0.3 & - \\
\hline 7-deoxy & 322 & 12.7 & 0.4 & 1.7 & 0.1 & 0.2 & 0.1 & 0.5 & 1.1 \\
\hline
\end{tabular}

${ }^{a}$ MS experiments were performed using a Shimadzu MS QP $1100 \mathrm{EX}$ equipment, with EI at $70 \mathrm{eV}$, with direct insertion probe, the ion source temperature $250{ }^{\circ} \mathrm{C}$ and the mass range was $40-500$ amu. ${ }^{b}$ The results are the averages for three independent experiments. " The "-" denotes that the fragment ion was not observed. ${ }^{\mathrm{d}}$ At $20 \mathrm{eV}$, ion source temperature $150{ }^{\circ} \mathrm{C}$. These conditions were used in order to increase the abundance of the peak of the molecular ion, other conditions and other products were not studied.

ion ([M-18u $\left.]^{+*}\right)$ near to $20 \%$ (23.0 and $17.0 \%$, respectively). Unfortunately, the mono-deuterium analogue, 6- $d_{l}$, did not allow us to conclude about the kind of the initial H-rearrangement, because the benzylic position contain one hydrogen and one deuterium. On the other hand, the tetra-deuterium analogue, $\mathbf{6}-d_{4}$, permitted us to confirm both initial rearrangement pathways, yielding two possible stable radical cations. The high abundance of the $[\mathrm{M}-18 \mathrm{u}]^{+*}$ ion in derivative 6- $d_{4}$, and the very low abundance in the parent compound, indicated the participation of the deuterium atom in a fragmentation process.

Further the deoxygenated derivatives 1-deoxy and 7-deoxy allowed us to establish that in the parent compounds the loss of oxygen, as expected, principally occurs from the $\mathrm{N}$-oxide moiety. The deoxy-derivatives showed the $[\mathrm{M}-16 \mathrm{u}]^{+*}$ ion in a very low abundance, i.e. abundance $\left([\mathrm{M}-16 \mathrm{u}]^{+*}\right) /$ abundance $\left(\mathrm{M}^{+*}\right)=0.002$ for 1deoxy and 0.031 for 7-deoxy (compare with the corresponding abundance $\left([\mathrm{M}-16 \mathrm{u}]^{+*}\right) /$ abundance $\left(\mathrm{M}^{+*}\right)$ values for $\mathbf{1}$ and 7, 0.032 and 0.71 respectively), probably due to an oxygen loss from the heterocycle system 1,2,5oxadiazole. In the deoxy-analogues the $[\mathrm{M}-17 \mathrm{u}]^{+\bullet}$ ion could be the result of a further $\mathrm{H}^{\bullet}$ loss. 


\section{Experimental}

All starting materials were commercially available research-grade chemicals and used without further purification. All solvents were dried and distilled prior to use. All the reactions were carried out in a nitrogen atmosphere. The typical work-up included washing with brine and drying the organic layer with sodium sulphate. Compounds 1-3, 1-i, 1-deoxy, 7, 7-deoxy, 15 and 16 were prepared as previously described. ${ }^{4,6,9,20,21}$ Elemental analyses were obtained from vacuum-dried samples (over phosphorous pentoxide, $24 \mathrm{~h}$ at room temperature) and performed on a Fisons EA 1108 CHNS-O analyzer, and were within $\pm 0.4 \%$ of theoretical values. Infrared spectra were recorded on a Perkin Elmer 1310 apparatus, using potassium bromide tablets; the frequencies are expressed in $\mathrm{cm}^{-1} .{ }^{1} \mathrm{H}-\mathrm{NMR}$ spectra and HETCOR experiments were recorded on a Bruker DPX-400 (at $400 \mathrm{MHz}$ and $100 \mathrm{MHz}$ ) instrument, with tetramethylsilane as the internal reference; the chemical shifts are reported in ppm. MS experiments were performed using the Shimadzu MS QP 1100 EX equipment, with $\mathrm{EI}$ at 20 or $70 \mathrm{eV}$, with direct insertion probe, the ion source was set a $150{ }^{\circ} \mathrm{C}$ or $250{ }^{\circ} \mathrm{C}$ and the mass range was 40-500 amu.

3-(1-Deuterio-1-hydroxymethyl)- $\mathrm{N}_{2}$-oxide-4-phenyl1,2,5-oxadiazole $\left(1-d_{1}\right)$. A solution of $2(1.0 \mathrm{~g}, 5.3 \mathrm{mmol})$ in THF $(5 \mathrm{~mL})$ was stirred at $0{ }^{\circ} \mathrm{C}$. Sodium borodeuteride $(220 \mathrm{mg}, 5.3 \mathrm{mmol}$ ) was then added, and the resulting solution was stirred for $3 \mathrm{~h}$ at room temperature. The solvent was removed in vacuo and the residue was dissolved in EtOAc. After the work-up process the residue was purified by column chromatography $\left(\mathrm{SiO}_{2}\right.$, petroleum ether:EtOAc (10 to $30 \%)$ ), to yield $600 \mathrm{mg}(59 \%), \mathrm{mp} 65.0-67.0{ }^{\circ} \mathrm{C}$; IR $v_{\max } / \mathrm{cm}^{-1}:$ OH 3400, 1560, 1410, 1050, 770, $680 \mathrm{~cm}^{-1} ;{ }^{1} \mathrm{H}$ NMR (deuteriochloroform): $\delta 2.30$ (bs, $1 \mathrm{H}, \mathrm{OH}), 4.73$ (s, $1 \mathrm{H},-\mathrm{CDHOH}), 7.57$ (m, 3H, phenyl protons), 7.84 (m, 2H, phenyl protons); ${ }^{13} \mathrm{C}$ NMR (HMQC and HMBC experiments) (deuteriochloroform): $\delta 53.40(-\mathrm{CDH}), 115.36$ (- $\left.C=\mathrm{N}^{+}-\mathrm{O}^{-}\right), 126.55$ (- $C$-phenyl), 128.18 (- $C$-phenyl), 129.80 (- $C$-phenyl), 131.76 (- $C$-phenyl), $157.31(-C=\mathrm{N})$. Anal. Calc for $\mathrm{C}_{9} \mathrm{H}_{7} \mathrm{DN}_{2} \mathrm{O}_{3}: \mathrm{C}, 55.96 ; \mathrm{H}, 3.63 ; \mathrm{N}, 14.51 \%$. Found: C, 56.00; H, 3.92; N, $14.35 \%$.

3-(1-Chloro-1-deuteriomethyl)- $\mathrm{N}_{2}$-oxide-4-phenyl1,2,5-oxadiazole $\left(3-d_{1}\right)$. A mixture of $\mathbf{1}-d_{1}(300 \mathrm{mg}, 1.6$ $\mathrm{mmol})$ and $\mathrm{SOCl}_{2}(0.19 \mathrm{~mL})$ was stirred at room temperature for $24 \mathrm{~h}$. The reaction mixture was treated with ice, sodium bicarbonate saturated solution (until basic $\mathrm{pH}$ ), and extracted three times with EtOAc $(20 \mathrm{~mL})$. Then of the work-up process the residue was purified by chromatography $\left(\mathrm{Al}_{2} \mathrm{O}_{3}\right.$, petroleum ether:EtOAc (0 to 5\%)) to yield $300 \mathrm{mg}$ (89\%), colorless oil; IR $v_{\max } / \mathrm{cm}^{-1}: 1601,1462$,
1435, 772, $696 \mathrm{~cm}^{-1} ;{ }^{1} \mathrm{H}$ NMR (deuteriochloroform): $\delta 4.57$ (s, $1 \mathrm{H},-\mathrm{CDHCl}), 7.56(\mathrm{~m}, 3 \mathrm{H}$, phenyl protons), $7.80(\mathrm{~m}$, $2 \mathrm{H}$, phenyl protons); ${ }^{13} \mathrm{C}$ NMR (HMQC and HMBC experiments) (deuteriochloroform): $\delta 32.94(-\mathrm{CDH}), 113.31$

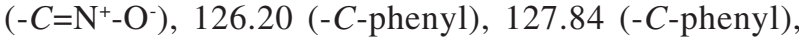
129.81 (- $C$-phenyl), 131.51 (- $C$-phenyl), $156.40(-C=\mathrm{N})$. Anal. Calc for $\mathrm{C}_{9} \mathrm{H}_{6} \mathrm{ClDN}_{2} \mathrm{O}_{2}: \mathrm{C}, 51.06 ; \mathrm{H}, 2.84 ; \mathrm{N}, 13.24 \%$. Found: C, 50.69; H, 2.99; N, 13.00\%.

4-(Chloromethyl)- $\mathrm{N}_{2}$-oxide-3-phenyl-1,2,5-oxadiazole (3-i). A mixture of 1-i (150 mg, $0.8 \mathrm{mmol})$ and $\mathrm{SOCl}_{2}(0.1$ $\mathrm{mL}$ ) was stirred at room temperature for $24 \mathrm{~h}$. The reaction mixture was treated with ice, sodium bicarbonate saturated solution (until basic $\mathrm{pH}$ ), and extracted three times with EtOAc $(20 \mathrm{~mL})$. Then of the work-up process the residue was purified by chromatography $\left(\mathrm{Al}_{2} \mathrm{O}_{3}\right.$, petroleum ether:EtOAc (0 to 5\%)) to yield $110 \mathrm{mg}(65 \%)$, colorless oil\%; IR $v_{\max } / \mathrm{cm}^{-1}: 1595,1450,1415,770,690 \mathrm{~cm}^{-1} ;{ }^{1} \mathrm{H}$ NMR (deuteriochloroform): $\delta 4.72$ (s, $2 \mathrm{H},-\mathrm{CH}_{2} \mathrm{Cl}$ ), 7.58 (m, 3H, phenyl protons), 7.83 ( $\mathrm{m}, 2 \mathrm{H}$, phenyl protons). Anal. Calc for $\mathrm{C}_{9} \mathrm{H}_{7} \mathrm{ClN}_{2} \mathrm{O}_{2}: \mathrm{C}, 51.31 ; \mathrm{H}, 3.33 ; \mathrm{N}, 13.30 \%$. Found: C, 51.07; H, 3.05; N, $12.92 \%$.

3-[1-Deuterio-1-(4-methylpiperazine-1-yl)methyl]- $\mathrm{N}_{2}$ oxide-4-phenyl-1,2,5-oxadiazole (6- $\left.d_{1}\right)$. A mixture of 3- $d_{1}$ (150 mg, $0.7 \mathrm{mmol}), N$-methylpiperazine $(65 \mathrm{mg}, 0.7$ $\mathrm{mmol}), \mathrm{K}_{2} \mathrm{CO}_{3}(100 \mathrm{mg}, 0.7 \mathrm{mmol}), \mathrm{KI}(10 \mathrm{mg}, 0.07 \mathrm{mmol})$ and THF as solvent was heated at reflux until absence of chloride $\left(\mathrm{Al}_{2} \mathrm{O}_{3}, 20 \%\right.$ EtOAc in petroleum ether). The solvent was removed in vacuum and the residue was purified by column chromatography $\left(\mathrm{Al}_{2} \mathrm{O}_{3}, \mathrm{CH}_{2} \mathrm{Cl}_{2}\right)$ to yield $100 \mathrm{mg}(51 \%), \mathrm{mp} 97.5-99.5{ }^{\circ} \mathrm{C}$; IR $v_{\text {max }} / \mathrm{cm}^{-1}: 2926$, $2797,1595,1574,1456,768,700 \mathrm{~cm}^{-1} ;{ }^{1} \mathrm{H}$ NMR (deuteriochloroform): $\delta 2.29\left(\mathrm{~s}, 3 \mathrm{H}, \mathrm{CH}_{3}-\mathrm{N}\right), 2.45(\mathrm{~m}, 4 \mathrm{H}$, $\left.-\mathrm{CH}_{2} \mathrm{~N}\right), 2.58\left(\mathrm{~m}, 4 \mathrm{H},-\mathrm{CH}_{2} \mathrm{~N}\right), 3.54(\mathrm{~s}, 1 \mathrm{H},-\mathrm{CDHN}), 7.52$ (m, $3 \mathrm{H}$, phenyl protons), 7.92 ( $\mathrm{m}, 2 \mathrm{H}$, phenyl protons); ${ }^{13} \mathrm{C}$ NMR (HMQC and HMBC experiments) (deuteriochloroform): $\delta 46.27\left(\mathrm{CH}_{3}-\mathrm{N}\right), 50.04(-\mathrm{CDH}), 53.10$ $\left(-\mathrm{CH}_{2}-\mathrm{N}\right), 55.23\left(-\mathrm{CH}_{2}-\mathrm{N}\right), 113.04\left(-C=\mathrm{N}^{+}-\mathrm{O}^{-}\right), 127.35$ (-C-phenyl), 128.52 (-C-phenyl), 129.47 (- $C$-phenyl), 131.45 (-C $C$-phenyl), $158.00(-C=\mathrm{N})$. Anal. Calc for $\mathrm{C}_{14} \mathrm{H}_{17} \mathrm{DN}_{4} \mathrm{O}_{2}: \mathrm{C}, 61.09 ; \mathrm{H}, 6.18 ; \mathrm{N}, 20.36 \%$. Found: $\mathrm{C}$, $60.96 ; \mathrm{H}, 6.30 ; \mathrm{N}, 20.22 \%$.

2,2,6,6-Tetradeuterio-4-methylpiperazine (17). A mixture of $N$-nitrosopiperazine tetradeuterated $16(190 \mathrm{mg}$, $1.4 \mathrm{mmol})$ in $\mathrm{MeOH}(5 \mathrm{~mL})$ was stirred at room temperature, Raney nickel (170 mg) was then added, and the air in the flask was replaced by hydrogen. The reaction mixture was vigorous stirred for 6 hours at room temperature. Raney nickel $(170 \mathrm{mg})$ was then added, and the system was resaturated with hydrogen and stirred for 1 hour at room temperature. The solution was decanted and filtered through Celite. The solvent was removed in vacuum and 
the residue was the product 17 (60 $\mathrm{mg}, 40 \%)$, which was used in the next reaction without further purification. ${ }^{1} \mathrm{H}$ NMR (deuteriochloroform): $\delta 2.00$ (s, 1H, NH), 2.35 (s, $\left.3 \mathrm{H}, \mathrm{CH}_{3}-\mathrm{N}\right), 2.36\left(\mathrm{~m}, 4 \mathrm{H},-\mathrm{CH}_{2} \mathrm{~N}\right)$.

3-[(4-Methyl-2,2,6,6-tetradeuteriopiperazine-1$y$ l)methyl]- $\mathrm{N}_{2}$-oxide-4-phenyl-1,2,5-oxadiazole (6-d $)$. A mixture of 3 (121 mg, $0.57 \mathrm{mmol}), 17$ (60 mg, $0.57 \mathrm{mmol}$ ), $\mathrm{K}_{2} \mathrm{CO}_{3}(80 \mathrm{mg}, 0.57 \mathrm{mmol}), \mathrm{KI}(8 \mathrm{mg}, 0.06 \mathrm{mmol})$ and THF as solvent was heated at reflux until absence of chloride $\left(\mathrm{Al}_{2} \mathrm{O}_{3}, 20 \%\right.$ EtOAc in petroleum ether). The solvent was removed in vacuum and the residue was purified by column chromatography $\left(\mathrm{Al}_{2} \mathrm{O}_{3}, \mathrm{CH}_{2} \mathrm{Cl}_{2}\right)$ to yield $40 \mathrm{mg}(25 \%)$, colorless oil; IR $v_{\max } / \mathrm{cm}^{-1}: 2917,2849,1599,1575,1456$, $767,699 \mathrm{~cm}^{-1} ;{ }^{1} \mathrm{H}$ NMR (acetone- $\left.d_{6}\right): \delta 2.30\left(\mathrm{~s}, 3 \mathrm{H}, \mathrm{CH}_{3}-\mathrm{N}\right)$, $2.51\left(\mathrm{~m}, 4 \mathrm{H},-\mathrm{CH}_{2} \mathrm{~N}\right), 3.63\left(\mathrm{~s}, 2 \mathrm{H}, \mathrm{Ar}-\mathrm{CH}_{2} \mathrm{~N}\right), 7.59(\mathrm{~m}, 3 \mathrm{H}$, phenyl protons), 8.02 (m, $2 \mathrm{H}$, phenyl protons); ${ }^{13} \mathrm{C} \mathrm{NMR}$ (HMQC and HMBC experiments) (acetone- $d_{6}$ ): $\delta 45.90$ $\left(\mathrm{CH}_{3}-\mathrm{N}\right), 50.00\left(\mathrm{Ar}-\mathrm{CH}_{2}-\mathrm{N}\right), 51.80\left(-\mathrm{CD}_{2} \mathrm{~N}\right), 54.00$ $\left(-C \mathrm{H}_{2}-\mathrm{N}\right), 113.50\left(-C=\mathrm{N}^{+}-\mathrm{O}^{-}\right), 126.00$ (-C -phenyl), 128.50 (-C-phenyl), 129.50 (-C-phenyl), 131.50 (-C-phenyl), $157.50(-C=\mathrm{N})$. Anal. Calc for $\mathrm{C}_{14} \mathrm{H}_{14} \mathrm{D}_{4} \mathrm{~N}_{4} \mathrm{O}_{2}: \mathrm{C}, 60.43 ; \mathrm{H}$, 5.04; N, 20.14\%. Found: C, 60.08; H, 5.44; N, $20.02 \%$.

\section{Crystallography}

Suitable needles shaped single crystals of $\mathbf{6}-d_{1}$ were obtained by slow evaporation from AcOEt. Derivative 6- $d_{1}$ crystallizes in the monoclinic $\mathrm{P} 2_{1} / \mathrm{c}$ space group with $\mathrm{a}=$ 10.906(3), $\mathrm{b}=14.581(3), \mathrm{c}=10.100(2) \AA, \beta=114.83(2)^{\circ}$ and $\mathrm{Z}=4$. The structure were solved from 1455 reflections with $\mathrm{I}>2 \mathrm{~s}(\mathrm{I})$ and refined to agreement R1-factors of 0.044 . Most $\mathrm{H}$-atoms were detected in a difference Fourier map. However, they were positioned stereochemically and refined with the riding model. The program used to solve and refine the structure was SHELXS. ${ }^{25}$ The program used to generate the ORTEP graphics was ORTEP-II. ${ }^{19}$

\section{Conclusions}

In summary, by using labeling experiments and adequate analogues, we were able to interpret EI/MS data to elucidate the fragmentation patterns in mass spectrometry of 1,2,5-oxadiazole $N$-oxide derivatives.

\section{Electronic Supplementary Information}

Listings of interatomic bond distances, selected angles, atomic anisotropic displacement parameters, hydrogen atoms positions and isotropic displacement parameters for derivative 6- $d_{1} \mathrm{X}$-ray studies. Available at http:// jbcs.sbq.org.br as a PDF file.

\section{Acknowledgement}

We thank the financial support from CONICYTUruguay (Grants 347/95 and 1019/95), Comisión Honoraria de Lucha contra el Cáncer (Uruguay), CONICET-Argentina and by FAPESP-Brazil. Part of the $\mathrm{X}$-ray diffraction experiments were carried out at the National Diffraction Laboratory (LANADI), La Plata, Argentina. We also thank Dr. Ana Denicola and Dr. Alvaro Diaz for critical reading of the manuscript.

\section{References}

1. Cerecetto, H.; González, M.; Onetto, S.; Risso, M.; Saenz, P.; Seoane, G.; Bruno, A.M.; Alarcon, J.; Olea-Azar, C.; López de Ceráin, A.; Ezpeleta, O.; Monge, A.; Med. Chem. Res. 2001, $10,328$.

2. Cerecetto, H.; Dias, E.; Di Maio, R.; González, M.; Pacce, S.; Saenz, P.; Seoane, G.; Suescun, L.; Mombrú, A.; Fernández, G.; Lema, M.; Villalba, J.; J. Agric. Food Chem. 2000, 48, 2995.

3. Monge, A.; López de Ceráin, A.; Ezpeleta, O.; Cerecetto, H.; Dias, E.; Di Maio, R.; González, M.; Onetto, S.; Risso, M.; Seoane, G.; Zinola F.; Olea-Azar, C.; Pharmazie 1998, 53, 698.

4. Monge, A.; López de Ceráin, A.; Ezpeleta, O.; Cerecetto, H.; Dias, E.; Di Maio, R.; González, M.; Onetto, S.; Seoane, G.; Suescun, L.; Mariezcurrena, R.; Pharmazie 1998, 53, 758.

5. Cerecetto, H.; González, M.; Risso, M.; Seoane, G.; López de Ceráin, A.; Ezpeleta, O.; Monge, A.; Suescun, L.; Mombrú, A.; Bruno, A.M.; Arch. Pharm. Pharm. Med. Chem. 2000, $333,387$.

6. Boiani, M.; Cerecetto, H.; González, M.; Risso, M.; Olea-Azar, C.; Piro, O.E.; Catellano, E.E.; López de Ceráin, A.; Ezpeleta, O.; Monge-Vega, A.; Eur. J. Med. Chem. 2001, 36, 771.

7. Cerecetto, H.; Di Maio, R.; González, M.; Risso, M.; Saenz, P.; Seoane, G.; Denicola, A.; Peluffo, G.; Quijano, C.; Olea-Azar, C.; J. Med. Chem. 1999, 42, 1941.

8. Aguirre, G.; Cerecetto, H.; Di Maio, R.; González, M.; Porcal, W.; Seoane, G.; Ortega, M.A.; Aldana, I.; Monge, A.; Denicola, A.; Arch. Pharm. Pharm. Med. Chem. 2002, 335, 15.

9. Fruttero, R.; Ferrarotti, B.; Serafino, A.; Di Stilo, A.; Gasco, A.; J. Heterocyclic Chem. 1989, 26, 1345; Gasco, A.M.; Fruttero, R.; Sorba, G.; Gasco, A.; Liebigs Ann. Chem. 1991, 1211; Gasco, A.; Mortarini, V.; Ruà, G.; Nano, G.M.; Menziani, E.; J. Heterocyclic Chem. 1972, 9, 577.

10. Hesse, M.; Meier, H.; Zeeh, B.; Spectroscopic Methods in Organic Chemistry; Thieme: New York, 1997.

11. Suwinski, J.; Svierczek, K.; J. Labelled Compd. Radiopharm. 2002, 45, 795 .

12. Vairamani, M.; Rao, K.; Rama, K.; Bhanumathi, N; Sattur, P.B.; Indian J. Chem. Sect. B 1990, 10, 944. 
13. McLafferty, F.D.; Turecek, F.; Interpretation of Mass Spectra, University Science Books: California, 1993.

14. Paudler, W.W.; Chen, T-K.; J. Org. Chem. 1971, 36, 787.

15. Sasaki, T.; Minamoto, K.; Nishikawa, M.; Shima, T.; Tetrahedron 1969, 25, 1021.

16. Hagen, D.F.; Haddad, L.C.; Marhevka, J.S.; Spectrochimica Acta 1987, 42, 253.

17. Mikaya, A.I.; Trusova, E.A.; Zaikin, V.G.; Volinsky, N.P.; Karaulova, E.N.; Galpern, G.D.; Org. Mass Spectrom. 1984, $19,428$.

18. As expected, the 1,2,5-oxadiazole heterocycle is planar to within experimental accuracy, with the oxygen atom of $\mathrm{N}$-oxide on the ring plane. $\mathrm{N}-\mathrm{O}$ bond distances in the heterocycle clearly reflect the asymmetry in the bonding structure imposed by the $\mathrm{N}$-oxide moiety. In fact, the single N1-O2 bond is appreciably longer (1.434(3) $\AA$ ) than the other, partially double, N2-O2 bond (1.371(3) Å). The phenyl ring subtends a dihedral angle of $39.20(9)^{\circ}$ with the heterocycle.
19. Johnson, C.K.; ORTEP-II. A Fortran Thermal-Ellipsoid Plot Program. Report ORNL-5138, Oak Ridge National Laboratory: Tennessee, USA, 1976.

20. Ravindran, T.; Jeyaraman, R.; Murray, R.W.; Singh, M.; J. Org. Chem. 1991, 56, 4833.

21. Keefer, L.K.; Fodor, C.H.; J. Am. Chem. Soc. 1970, $92,5747$.

22. Kano, S.; Tamaka, Y.; Sugino, E.; Hibino, S.; Synthesis 1980, 741.

23. Enders, D.; Pieter, R.; Renger, B.; Seebach, D.; Org. Syn. 1978, 58, 113.

24. Aoyagi, Y.; Abe, T.; Ohta, A.; Synthesis 1997, 8, 891.

25. Sheldrick, G.M.; SHELXS-97. Program for Crystal Structure Resolution, University of Göttingen: Göttingen, Germany, 1997.

Received: January 30, 2003

Published on the web: February 27, 2004

FAPESP helped in meeting the publication costs of this article. 